\title{
NOTE
}

\section{Nitrogen isotopic composition of marine and freshwater invertebrates}

\author{
R. L. France \\ Department of Biology, McGill University, 1205 Ave. Dr. Penfield, Montreal, Quebec, Canada H3A 1B1
}

\begin{abstract}
Stable nitrogen isotopes have customarily been used to delineate trophic position with only scant regard to source variability in isotopic composition. A compilation of literature data indicates, however, that marine invertebrates are enriched in ${ }^{15} \mathrm{~N}$ relative to those inhabiting freshwaters Estuarine mussels were also found to have intermediate $\delta^{15} \mathrm{~N}$ values which reflected their location along a freshwatermarine gradient. The use of invertebrate $\delta^{15} \mathrm{~N}$ as a measure of continental-marine coupling in complex coastal environments could therefore provide additional support for conclusions based on traditional $\delta^{13} \mathrm{C}$ analysis.
\end{abstract}

KEY WORDS: $\delta^{15} \mathrm{~N} \cdot$ Freshwater and manine invertebrates Source enrichment

It is now widely accepted that a 3 to $4 \%$ fractionation in stable nitrogen isotopes occurs with food assimilation (Owens 1987). Some parallel work has indicated, however, that $\delta^{15} \mathrm{~N}$ (ratio of ${ }^{15} \mathrm{~N} /{ }^{14} \mathrm{~N}$ expressed as deviations from the recognized isotopic standard, in \%ol may also function as a source marker of material flow across ecotones. In oceans, for example, variability in $\delta^{15} \mathrm{~N}$ among animals depends upon process differences in internal cycling of 'old' and 'new' nitrogen (e.g. Rau 1981, Mullin et al. 1984, Checkley \& Entzeroth 1985, Fisher et al. 1994). In estuarine and coastal environments, mixing of materials derived from terrestrial and oceanic sources has been assessed through $\delta^{15} \mathrm{~N}$ analysis of both suspended (Mariotti et al. 1984, Owens 1985. Croft et al. 1988) and deposited (Peters et al. 1978, Owens 1987) organic matter.

Broad-scale, continental-marine differences in $\delta^{15} \mathrm{~N}$ may also exist. The bone collagen of 64 mammals, 17 birds, and 17 fishes showed that marine animals have $\delta^{15} \mathrm{~N}$ values which average 6 to $10 \%$ higher $\left({ }^{15} \mathrm{~N}\right.$ enriched) than those for terrestrial or freshwater organisms (Schoeninger \& DeNiro 1984). The low sample sizes (98 measurements) and narrow faunal range (66 vertebrate species) of this previous study limits conclusions about the generality of broad-scale environmental differences in source variability of $\delta^{15} \mathrm{~N}$ [see Owens (1987) and Gearing (1988) for different interpretations]. To counter these limitations, the present investigation compiled literature data on over 400 measurements of $\delta^{15} \mathrm{~N}$, representing hundreds of different invertebrate species, to determine if marine animals are indeed enriched in ${ }^{15} \mathrm{~N}$ relative to organisms inhabiting freshwaters.

Stable nitrogen values were obtained from tables and from figures with a digitizing reader. Data sources included Wada \& Hattori (1976), Pang \& Nriagu (1977), Macko et al. (1982), Checkley \& Entzeroth (1985), Peterson \& Howarth (1987), Yoshioka et al. (1989), Montoya et al. (1990), Rau et al. (1990, 1991), Toda \& Wada (1990), and Mihuc \& Toetz (1994), in addition to those studies listed in France (1995).

Invertebrate $\delta^{15} \mathrm{~N}$ was found to reflect both trophicdietary and habitat-source fractionation. Over half of the organisms had $\delta^{15} \mathrm{~N}$ values within a single trophic position of one another (i.e. $\pm 2 \%$ ) as centred about their respective modes in each data grouping (Figs. 1 \& 2). The relative position of these modes, however, were found to be different for marine and freshwater invertebrates. Marine zooplankton (mode and mean = 10\%) and zoobenthos (mode and mean $=9 \%$ ) were on average enriched about 3 to $4 \%$ in $\delta^{15} \mathrm{~N}$ compared to freshwater zooplankton (mode $=6 \%$, mean $=7 \%$ ) and zoobenthos (mode and mean $=6 \%$ ). Therefore, Schoeninger \& DeNiro's (1984) belief in broad-scale environmental differences in $\delta^{15} \mathrm{~N}$ between marine and freshwater animals, which they based on collagen samples of 17 fishes, is supported by the present compilation of whole-body samples for 443 invertebrates. 

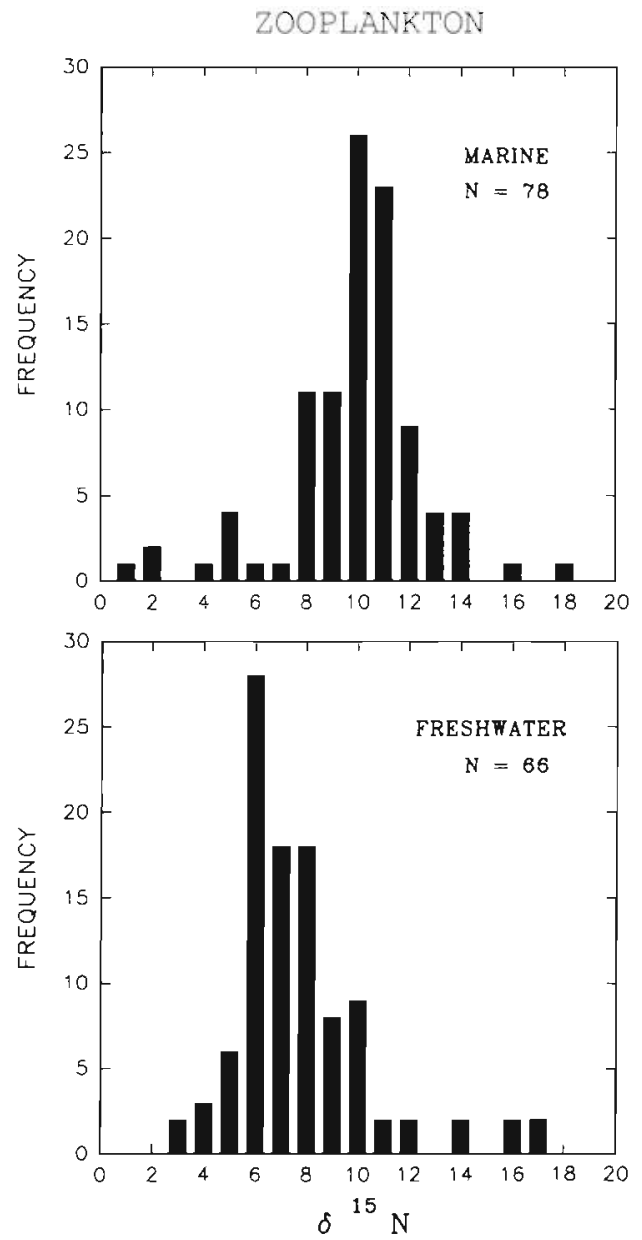

Fig. 1. Percentage frequency distributions of stable nitrogen isotope ratios for marine and fresh water zooplankton

Within a single species, analysis of $\delta^{15} \mathrm{~N}$ can be used to measure the dietary proportion of food originating from different environmental sources. For example, a reanalysis of mussel data from Peterson et al. (1985) indicates that the $\delta^{15} \mathrm{~N}$ of estuarine invertebrates reflects the degree of terrestrial-oceanic mixing (Fig. 3). This substantiates Schoeninger \& DeNiro's (1984) finding of intermediate $\delta^{15} \mathrm{~N}$ values for organisms such as migratory birds and anadromous fishes which spend part of their life cycles feeding in both freshwater and marine envirorments.

The use of invertebrate $\delta^{15} \mathrm{~N}$ as a marker of ecotonal coupling in coastal environments could therefore provide additional support for conclusions based on the traditional analysis (e.g. Incze et al. 1982, Stephenson \& Lyon 1982) of $\delta^{13} \mathrm{C}$ alone.

Acknowledgements. This work was funded by a Canadian NSERC Strategic Grant for work on terrestrial-aquatic coupling. J. Blais, R. Peters, and G. Cabana are thanked for many fruitful conversations about nitrogen isotope variability, as is R. Peters for a review of the manuscript.
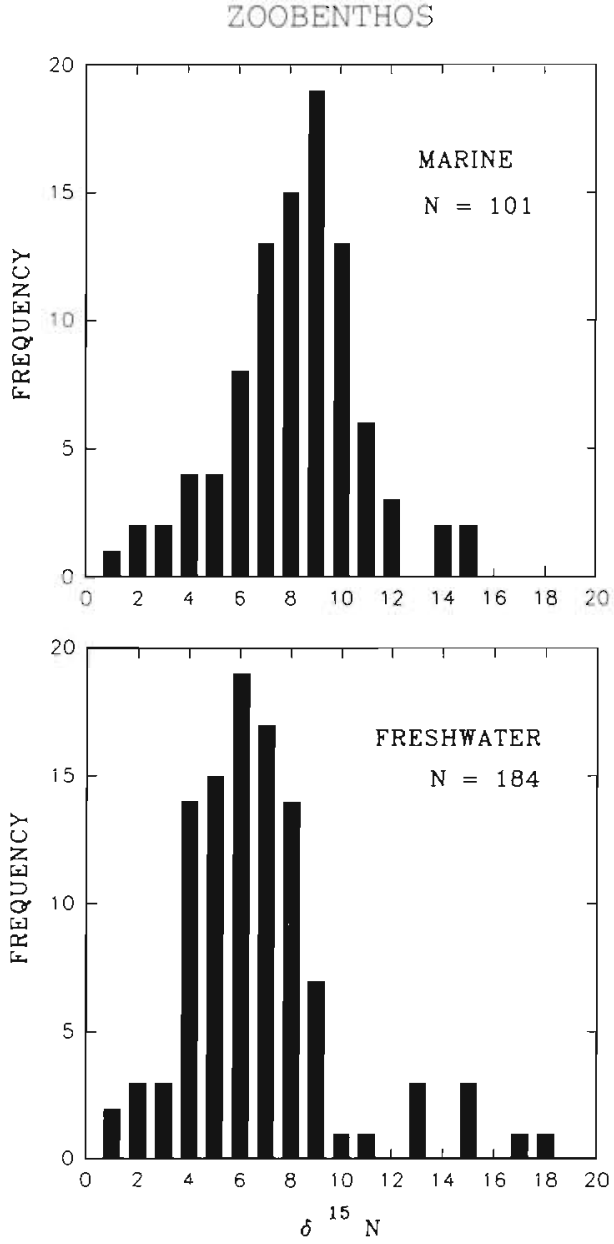

Fig. 2. Percentage frequency distributions of stable nitrogen isotope ratios for marine and freshwater zoobenthic invertebrates

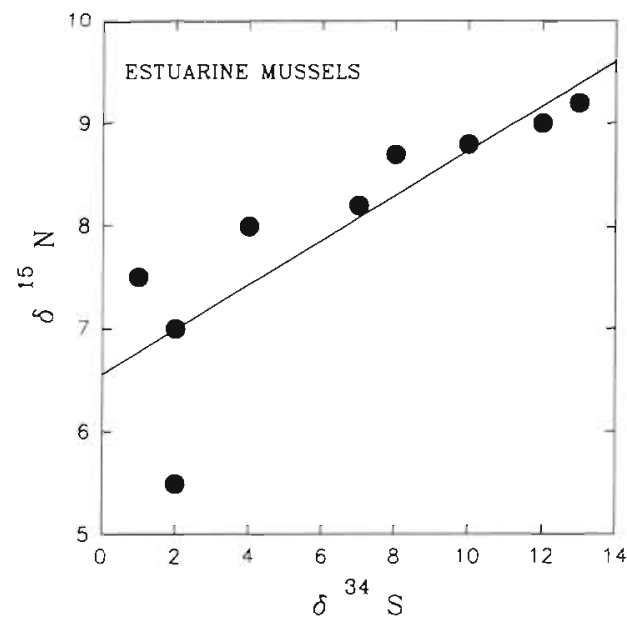

Fig. 3. Relationship between stable isotopes of nitrogen and sulfur for mussels (Geukensia demissa) in an estuary (reanalysis of data from Peterson et al. 1985). The sulfur isotopic signature for marine sediments is about $15 \%$ while that for freshwater sediments is below 0 


\section{LITERATURE CITED}

Checkley, D. M., Entzeroth, L. C. (1985). Elemental and isotopic fractionation of carbon and nitrogen by marine, planktonic copepods and implications to the marine nitrogen cycle. J. Plankton Res. 7: 553-568

Croft, C. B., Broome, S. W., Seneca, E. D., Showers, W. J. (1988). Estimating sources of soil organic matter in natura] and transplanted estuarine marshes using stable isotopes of carbon and nitrogen. Estuar. coast. Shelf Sci. 26: 633-641

Fisher, C. R., Childress, J. J., Macko, S. A., Brooks, J. M. (1994). Nutritional interactions in Galapagos Rift hydrothermal vent communities: inferences from stable carbon and nitrogen isotope analyses. Mar. Ecol. Prog. Ser. 103 : 45-55

France, R. (1995). Stable nitrogen isotopes in fish: literature synthesis on the influence of ecotonal coupling. Estuar. coast. Shelf Sci. (in press)

Gearing, J. N. (1988). The use of stable isotope ratios for tracing the nearshore-offshore exchange of organic matter. Lect. Notes coast. Estuar. Interact. 22: 69-101

Incze, L. S., Mayer, L. M., Sherr, E. B., Macko, S. A. (1982). Carbon inputs to bivalve mollusks: a comparison of two estuaries. Can. J. Fish. Aquat. Sci. 39: 1348-1352

Macko, S. A., Lee, W. Y., Parker, P. L. (1982). Nitrogen and carbon isotope fractionation by two species of marine amphipods: laboratory and field studies. J. exp. mar. Biol. Ecol. 63: 145-149

Mariotti, A., Lancelot, C., Billen, G. (1984). Natural isotopic composition of nitrogen as a tracer of origin for suspended organic matter in the Scheldt estuary. Geochim. Cosmochim. Acta 48: 549-555

Mihuc, T., Toetz, D. (1994). Determination of diets of alpine insects using stable isotopes and gut analysis. Am. Midl. Nat. 131: 146-155

Montoya, J. P., Horrigan, C. G., McCarthy, J. J. (1990). Natural abundance of ${ }^{15} \mathrm{~N}$ in particulate nitrogen and zooplankton in Chesapeake Bay. Mar. Ecol. Prog. Ser. 65: 35-61

Mullin, M. M., Rau, G. H., Eppley, R. W. (1984). Stable nitrogen isotopes in zooplankton: some geographic and temporal variations in the North Pacific. Limnol. Oceanogr. 29: 1267-1273

Owens, N. J. P. (1985). Variations in the natural abundance of

This note was submitted to the editor $\delta^{15} \mathrm{~N}$ in estuarine suspended particulate organic matter: a specific indicator of biological processing. Estuar. coast. Shelf Sci. 20: 505-510

Owens, N. J. P. (1987). Natural variations in ${ }^{15} \mathrm{~N}$ in the marine environment. Adv. mar. Biol. 24: 389-451

Pang, R. C., Nriagu, J. O. (1977). Isotopic variations of the nitrogen in Lake Supenor Geochim. Cosmochim. Acta 41. 811-814

Peters, K. E., Sweeney, R. E., Kaplan, I. R. (1978). Correlation of carbon and nitrogen stable isotope ratios in sedimentary organic matter. Limnol. Oceanogr. 23: 598-604

Peterson, B. J., Howarth, R. W. (1987). Sulfur, carbon, and nitrogen isotopes used to trace organic matter flow in the salt-marsh estuaries of Sapelo Island, Georgia. Limnol. Oceanogr. 32: 1195-1213

Peterson, B. J., Howarth, R. W., Garritt, R. H. (1985). Multiple stable isotopes used to trace the flow of organic matter in estuarine food webs. Science 227: 1361-1363

Rau, G. H. (1981). Low ${ }^{15} \mathrm{~N} /{ }^{14} \mathrm{~N}$ in hydrothermal vent animals: ecological implications. Nature 289: 484-485

Rau, G. H., Hopkins, T. L., Torres, J. L. (1991). ${ }^{15} \mathrm{~N} /{ }^{14} \mathrm{~N}$ and ${ }^{13} \mathrm{C} /{ }^{12} \mathrm{C}$ in Weddell Sea invertebrates: implications for feeding diversity. Mar. Ecol. Prog. Ser. 77: 1-6

Rau, G. H., Teyssie, J. L., Rassoulzadegan, F., Fowler, S. W. (1990). ${ }^{12} \mathrm{C} /{ }^{13} \mathrm{C}$ and ${ }^{15} \mathrm{~N} /{ }^{14} \mathrm{~N}$ variations among sizefractionated marine particles: implications for their origin and trophic relationships. Mar. Ecol. Prog. Ser. 59: 33-38

Schoeninger, M. J., DeNiro, M. J. (1984). Nitrogen and carbon isotopic composition of bone collagen from marine and terrestrial animals. Geochim. Cosmochim. Acta 48: $625-639$

Stephenson, R. L., Lyon, G. L. (1982). Carbon-13 depletion in an estuarine bivalve: detection of marine and terrestrial sources. Oecologia 55: 110-113

Toda, H., Wada, E. (1990). Use of ${ }^{15} \mathrm{~N} /{ }^{14} \mathrm{~N}$ rations to evaluate the food source of the mysid. Neomysis intermedia Czerniawsky, in a eutrophic lake in Japan. Hydrobiologia 122: $21-29$

Wada, E., Hattori, A. (1976). Natural abundance of ${ }^{15} \mathrm{~N}$ in particulate organic matter in the North Pacific Ocean. Geochim. Cosmochim. Acta 40: 249-251

Yoshioka, T., Hayashi, H., Wada, E. (1989). Seasonal variation of carbon and nitrogen isotope ratios of plankton and sinking particles in Lake Kizaki. Jap. J. Limnol. 50: 313-320

Manuscript first received: April 5, 1994

Revised version accepted: July 7, 1994 